\title{
COMPARATIVE STUDY OF MATERNAL RISK FACTORS INFLUENCING LOW BIRTH WEIGHT BABIES DELIVERED IN A TERTIARY CARE TEACHING HOSPITAL
}

\author{
B. Ramesh Kumar', A. Thirupathi Reddy², D. Ramesh Krishna ${ }^{3}$ \\ ${ }^{1}$ Assistant Professor, Department of Paediatrics, Guntur Medical College, Guntur. \\ ${ }^{2}$ Associate Professor, Department of Paediatrics, Guntur Medical College, Guntur. \\ 3Junior Resident, Department of Paediatrics, Guntur Medical College, Guntur.
}

ABSTRACT
BACKGROUND
India is one of the leading countries with more Low Birth Weight (LBW) babies in the world contributing significantly to more
neonatal and infantile mortality rates. This study aims to identify the various maternal and obstetric risk factors leading to low
birth weight in babies.

\section{MATERIALS AND METHODS}

This is a retrospective case control hospital-based comparative study conducted at neonatal intensive care unit, Department of Paediatrics and labour room, Department of Obstetrics attached to Guntur Medical College and Hospital, Guntur, Andhra Pradesh, India from Sept. 2015 to Aug. 2016 over a period of 1 year. Anthropometric data and maternal risk factors of $250 \mathrm{LBW}$ (<2500 gm) babies and 250 normal birth weight (> $2500 \mathrm{gm}$ ) babies were selected randomly by using systematic randomisation method and compared after analysing the data recorded in a predesigned proforma by using the appropriate statistical methods, i.e. \%, $\mathrm{CHI}^{2}$ and regression statistics with SPSS 16 Software and results were documented in a tabular form using Fisher tables. Sample size was taken by using formula $\mathrm{n}=4 \mathrm{pq} / \mathrm{l}^{2} \mathrm{n}=$ sample size, $\mathrm{p}=$ incidence (18.3), $\mathrm{q}=100-\mathrm{p}(81.7), \mathrm{l}=$ allowable error that is $5 \%$. So here $\mathrm{n}=239$, that is why we have taken 250 as a sample size for easy calculations.

\section{RESULTS}

Our study shows that the Incidence of LBW is $18.03 \%$. The statistically significant risk factors of mothers with LBW babies identified in our study are: Out of 250 mothers of LBW babies, $134(53.6 \%)$ were aged < 20 years; $151(60.4 \%)$ were < $145 \mathrm{~cm}$ by height; 32 (12.8\%) were found to have preconception weight < $40 \mathrm{~kg}$; maternal weight gain of < $7 \mathrm{~kg}$ was found in $59(23.6 \%) ; 152$ (60.8\%) were anaemic; 42 (16.8\%) had Pregnancy Induced Hypertension (PIH) and 19 (7.6\%) had urinary tract infection.

\section{CONCLUSION}

The overall prevalence of low birth weight in our study was $18 \%$. The factors observed to be significantly associated with low birth weight in our study include maternal age $<20$ years, maternal height $<145 \mathrm{cms}$, preconception weight $<40 \mathrm{~kg}$, maternal weight gain $<7 \mathrm{~kg}$ during pregnancy and anaemia in the mother. The results of this study suggest that to reduce the low birth weight, health programme should focus on maternal nutrition and nutritional education to facilitate better weight gain during pregnancy and discourage pregnancy at early age. Early identification of anaemia and other maternal risk factors and their interventions with good antenatal care will decrease the low birth weight in India.

\section{KEYWORDS}

Low Birth Weight, Maternal Risk Factors, Anthropometry, Prevalence, India.

HOW TO CITE THIS ARTICLE: Kumar BR, Reddy AT, Krishna DR. Comparative study of maternal risk factors influencing low birth weight babies delivered in a tertiary care teaching hospital. J. Evolution Med. Dent. Sci. 2017;6(36):2963-2967, D0I: $10.14260 /$ Jemds/2017/638

\section{BACKGROUND}
Newborn care always has been a challenge to paediatrician and more so with the Low Birth Weight (LBW) babies. Low birth weight has been defined by the World Health Organisation (WHO), as weight at birth of less than $2500 \mathrm{gm}$. There is no indicator in human biology, which tell us so much about the past events and future trajectory of life as the weight of the baby at birth. ${ }^{1}$ Low birth weight is considered to
Financial or Other, Competing Interest: None.
Submission 28-03-2017, Peer Review 22-04-2017,
Acceptance 27-04-2017, Published 04-05-2017.
Corresponding Author:
B. Ramesh Kumar,
Flat No. 203, Easwari Residency,
$1^{\text {st }}$ Lane KVP Colony, Chuttugunta,
Guntur-522004.
E-mail:drbanam@gmail.com
DOI: $10.14260 / \mathrm{jemds} / 2017 / 638$
be the single most important predictor of infant mortality, especially deaths within the first month of life. ${ }^{2}$ It continues to remain a major public health problem worldwide, especially in the developing countries. More than 20 million low birth weight babies are born every year throughout the world, in spite of considerable efforts to improve the maternal and child health quality. About half of all deaths in perinatal period are directly or indirectly related to low birth weight. $^{3}$ Low birth weight is the strongest determinant of infant morbidity and mortality in India. By NFHS-3 report, proportion of low birth weight babies were found to be $23 \%$ for rural and $19 \%$ for urban population. ${ }^{4}$ India alone has more than 7 million low birth weight babies. In countries where the population of low birth weight infants is less, short gestational period is the major cause. In countries where the proportion is high (e.g. India), the majority of cases can be attributed to foetal growth retardation. ${ }^{5}$ The causes of low birth weight are complex and interdependent and various 
maternal factors are known to influence the birth weight of neonates. Maternal age, anthropometric parameters such as maternal height, weight, weight gain during pregnancy, anaemia, nutritional status and socioeconomic status are some of the well-established determinants of birth weight of the neonates. ${ }^{6}$

Birth weight is an important determinant of success and duration of breast feeding, which is a well-known protective asset against infant deaths in developing countries, ${ }^{7}$ neurodevelopmental sequelae of birth asphyxia are three times high in low birth weight babies compared to their normal weight counterparts. ${ }^{8}$ These low birth weight babies are more vulnerable to develop atherosclerotic coronary artery disease, hypertension and diabetes mellitus during adult life. ${ }^{9}$ Small for date babies may remain stunted throughout life. ${ }^{10}$ If the maternal risk factors associated with low birth weight are detected early and addressed properly, the low birth weight and the consequences thereof can be reduced in India. ${ }^{11}$

So there is an urgent need to know the local prevalence of low birth weight babies and various maternal risk factors contributing to it. The present study is required to carry out at our Institute to identify the local maternal risk factors responsible for low birth weight babies in our area, so as to provide better preventive maternal and neonatal health services so that the morbidity and mortality can be reduced to a significant level in low birth weight babies.

\section{MATERIALS AND METHODS}

The present study was conducted in neonatal intensive care unit, Department of Paediatrics and labour room, Department of Obstetrics, Guntur Medical College and Government General Hospital, Andhra Pradesh, India. The study was approved by Institutional Ethical Committee and parental informed consent was taken.
The present study conducted from Sept. 2015 to August 2016 , over a period of 1 year recorded the data of 250 low birth weight babies and their mothers along with 250 normal birth weight babies and their mothers were collected retrospectively by systematic randomisation. The weight of the neonate was recorded nude on electronic weighing scale within first hour of birth and other anthropometric parameters like length, head circumference, chest circumference were recorded. Gestational age assessment of the newborn was done by using modified Ballard score. Height of the mother, preconceptional weight, weight gain during pregnancy was recorded along with elaborative history, presence of risk factors, socioeconomic status and clinical examination details were documented in a predesigned proforma. The data that was collected was analysed using standard statistical methods (Percentage, $\mathrm{P}$ value, chi square by using regression statistics with SPSS 16.0 Version) and the results were documented in a tabular form by using Fisher tables. Sample size was taken by using formula $\mathrm{n}=4 \mathrm{pq} / \mathrm{l}^{2} \mathrm{n}=$ sample size, $\mathrm{p}=$ incidence $(18.3), \mathrm{q}=$ $100-p$ (81.7), $\mathrm{l}=$ allowable error that is $5 \%$. So here $\mathrm{n}=239$, that is why we have taken 250 as a sample size for easy calculations.

\section{RESULTS}

The data of 250 normal birth weight babies and their mothers along with 250 low birth weight babies and their mothers were collected and analysed by standard statistical methods.

\begin{tabular}{|c|c|}
\hline Total Deliveries & 6543 \\
\hline No. of low birth weight babies & 1180 \\
\hline \multicolumn{2}{|c|}{ Table 1. Incidence of Low Birth Weight } \\
\hline
\end{tabular}

Our study incidence of LBW is $18.03 \%$ during a 1 -year period from September 2015 to August 2016.

\begin{tabular}{|c|c|c|c|c|c|}
\hline \multirow[t]{2}{*}{ S1. No. } & \multirow[t]{2}{*}{ Maternal Risk Factors } & $\begin{array}{c}\text { Low Birth } \\
\text { Weight Babies }\end{array}$ & $\begin{array}{c}\text { Normal Birth } \\
\text { Weight Babies }\end{array}$ & \multirow{2}{*}{$\begin{array}{l}\left(\mathrm{X}^{2}\right) \text { Value with } \\
1 \text { Degree Freedom }\end{array}$} & \multirow{2}{*}{$\begin{array}{l}\text { Statistical } \\
\text { Significance }\end{array}$} \\
\hline & & No. \& \% & No. \& \% & & \\
\hline 1 & Age $<20$ years & $\begin{array}{c}134 \\
(53.6 \%)\end{array}$ & $\begin{array}{c}113 \\
(45.2 \%)\end{array}$ & $\begin{array}{c}<0.0001 \\
\left(\mathrm{X}^{2}\right) \text { value }=94.287\end{array}$ & Significant \\
\hline 2 & Height $<145 \mathrm{~cm}$ & $\begin{array}{c}151 \\
(60.4 \%)\end{array}$ & $\begin{array}{c}45 \\
(18 \%) \\
\end{array}$ & $\begin{array}{c}<0.001 \\
\left(\mathrm{X}^{2}\right) \text { value }=94.287\end{array}$ & Significant \\
\hline 3 & $\begin{array}{l}\text { Preconceptional } \\
\text { Weight }<40 \mathrm{~kg}\end{array}$ & $\begin{array}{c}32 \\
(12.8 \%)\end{array}$ & $\begin{array}{c}3 \\
(12 \%)\end{array}$ & $\begin{array}{c}<0.0001 \\
\left(\mathrm{X}^{2}\right) \text { value }=25.837\end{array}$ & Significant \\
\hline 4 & $\begin{array}{l}\text { Weight gain during } \\
\text { pregnancy }<7 \mathrm{~kg}\end{array}$ & $\begin{array}{c}59 \\
(23.6 \%)\end{array}$ & $\begin{array}{c}4 \\
(1.6 \%)\end{array}$ & $\begin{array}{c}<0.0001 \\
\left(\mathrm{X}^{2}\right) \text { value }=54.938\end{array}$ & Significant \\
\hline 5 & $\begin{array}{c}\text { Maternal anaemia }(\mathrm{Hb} \%<10 \\
\text { gms } \%)\end{array}$ & $\begin{array}{c}152 \\
(60.8 \%)\end{array}$ & $\begin{array}{c}75 \\
(30 \%)\end{array}$ & $\begin{array}{c}<0.0001 \\
\left(\mathrm{X}^{2}\right) \text { value }=94.287\end{array}$ & Significant \\
\hline 6 & P.I.H & $\begin{array}{c}42 \\
(16.8 \%)\end{array}$ & $\begin{array}{c}8 \\
(3.2 \%) \\
\end{array}$ & $\begin{array}{c}<0.0001 \\
\left(\mathrm{X}^{2}\right) \text { value }=54.938\end{array}$ & Significant \\
\hline 7 & U.T.I & $\begin{array}{c}19 \\
(7.6 \%)\end{array}$ & $\begin{array}{c}0 \\
(0 \%) \\
\end{array}$ & - & Not Significant \\
\hline 8 & \begin{tabular}{|c|} 
Other medical complication \\
(heart diseases, renal disease, \\
connective tissue diseases)
\end{tabular} & $\begin{array}{c}10 \\
(05 \%)\end{array}$ & $\begin{array}{c}0 \\
(0 \%)\end{array}$ & - & Not Significant \\
\hline
\end{tabular}

\footnotetext{
Table 2. Relative Proportions of various Maternal Risk Factors
} 
Relation between Maternal Age and Birth Weight

Out of 250 mothers of low birth weight babies, 134 (53\%)

were aged less than 20 years compared to $113(45.2 \%)$

mothers with normal birth weight.

\section{Relation between Maternal Height and Birth Weight}

$151(60.4 \%)$ mothers of low birth weight were less than 145 $\mathrm{cm}$ by height, whereas only $45(18 \%)$ out of 250 mothers of normal birth weight babies were less than $145 \mathrm{~cm}$ in height.

\section{Relation between Preconceptional Weight and Birth Weight}

$32(12.8 \%)$ out of 250 mothers of low birth weight babies and $3(1.2 \%)$ out of 250 mothers of normal birth weight babies were found to have preconceptional weight less than $40 \mathrm{~kg}$.

Relation between Maternal Weight Gain during Pregnancy and Birth Weight

$59(23.6 \%)$ out of 250 mothers of low birth weight babies gained weight less than $7 \mathrm{~kg}$ during pregnancy compared to 4 (1.6\%) out of 250 mothers with normal birth weight.

\section{Relation between Maternal Anaemia and Birth Weight}

Out of 250 mothers of low birth weight babies 152 (60.8\%) are anaemic, whereas $75(30 \%)$ mothers of normal birth weight babies are anaemic.

\section{Relation between Pregnancy-Induced Hypertension and} Birth Weight

$42(16.8 \%)$ mothers of low birth weight babies had pregnancy-induced hypertension, whereas only 8 (3.2\%) mothers of normal birth weight babies had pregnancyinduced hypertension.

\section{Relation between Urinary Tract Infection and Birth Weight}

In the present study 19 (7.6\%) mothers of low birth weight babies had UTI, which was not at all observed in mothers of normal birth weight babies.

\section{Relation between Systemic Medical Conditions and Birth Weight}

Only 10 (4\%) out of 250 mothers with low birth weight babies had heart disease, renal disease and connective tissue disease. None of the mothers of normal birth weight babies suffered from any systemic disease.

\section{Relation between Other Risk Factors and Birth Weight}

$15(6 \%)$ mothers of low birth weight babies had previous history of low birth weight babies; 12 (4.8\%) mothers of low birth weight babies had premature rupture of membranes; 6 (2.4\%) mothers of low birth weight babies had bleeding per vagina. Such risk factors were not observed in mothers of normal birth weight babies in our study.

\section{DISCUSSION}

The data from present study are compared for discussion with previous studies done.

\begin{tabular}{|c|c|c|c|}
\hline $\begin{array}{c}\text { Sl. } \\
\text { No. }\end{array}$ & Author of Study & $\begin{array}{c}\text { Incidence of } \\
\text { Low Birth } \\
\text { Weight }\end{array}$ & $\begin{array}{l}\text { Our } \\
\text { Study }\end{array}$ \\
\hline 1 & $\begin{array}{l}\text { KS Nagi, SD Kandpal, M } \\
\text { Kukreti (1998) }{ }^{12}\end{array}$ & $23.8 \%$ & \multirow{6}{*}{$18.03 \%$} \\
\hline 2 & Trivedi et al (1996) ${ }^{13}$ & $20.37 \%$ & \\
\hline 3 & Kamaladas et al ${ }^{14}$ & $24.6 \%$ & \\
\hline 4 & $\begin{array}{c}\text { Mukesh K Sharma, Dinesh } \\
\text { Kumar, Anju Huria, Prakash } \\
\text { Gupta, Chandigarh }(2007)^{15}\end{array}$ & $23.8 \%$ & \\
\hline 5 & SK Kapoor et al ${ }^{16}$ & $8.8 \%$ & \\
\hline 6 & $\begin{array}{l}\text { National Family Health } \\
\text { Survey- } 3^{4}\end{array}$ & $21.5 \%$ & \\
\hline \multicolumn{4}{|c|}{ Table 3. Prevalence of Low Birth Weight } \\
\hline
\end{tabular}

The overall incidence of low birth weight in our study was $18.03 \%$. It is closely co-relating with other studies. ${ }^{12,13,14,15,16}$

The prevalence of low birth weight according to NFHS-3 was $21.5 \%$.

\begin{tabular}{|c|c|c|c|}
\hline $\begin{array}{c}\text { Sl. } \\
\text { No. }\end{array}$ & $\begin{array}{c}\text { Author of } \\
\text { Study }\end{array}$ & $\begin{array}{c}\text { Percentage of } \\
\text { Mothers }\end{array}$ & $\begin{array}{c}\text { Our } \\
\text { Study }\end{array}$ \\
\hline 1 & $\begin{array}{c}\text { S. Ganesh Kumar et } \\
\text { al }^{17}\end{array}$ & $14 \%$ & \multirow{2}{*}{$53.6 \%$} \\
\hline 2 & Lt. Col. G. Singh et al 18 & $36.4 \%$ & \\
\hline 3 & Deepa H Velankar ${ }^{19}$ & $67 \%$ & \\
\cline { 1 - 1 } \multicolumn{2}{|c|}{ Table 4. Maternal Age and Birth Weight } \\
\hline
\end{tabular}

Maternal age $<20$ years is a risk factor for low birth weight.

In the present study among the mothers of low birth weight babies, $53.6 \%$ were aged $<20$ years which was higher when compared to previous studies (G. Ganesh Kumar et al $14 \%$, Lt. Col. G. Singh et al 36.4\%). But the value is less when compared to the study of Deepa H. Velankar (67\%).

\begin{tabular}{|c|c|c|c|}
\hline $\begin{array}{l}\text { SL. } \\
\text { No. }\end{array}$ & Author of Study & $\begin{array}{c}\text { Percentage of } \\
\text { Risk }\end{array}$ & Our Study \\
\hline 1 & Hirve SS, Ganatra BR ${ }^{20}$ & $29.5 \%$ & \multirow{3}{*}{$60.4 \%$} \\
\hline 2 & $\begin{array}{c}\text { S Ganesh Kumar } \\
\text { et al }{ }^{17}\end{array}$ & $18 \%$ & \\
\hline 3 & Deepa H Velankar ${ }^{19}$ & $60.6 \%$ & \\
\hline \multicolumn{4}{|c|}{ Table 5. Maternal Height and Birth Weight } \\
\hline
\end{tabular}

Maternal height of $<145 \mathrm{~cm}$ is a known risk factor for low birth weight babies.

In the present study, maternal height of $<145 \mathrm{~cm}$ was found in $60.4 \%$ of mothers of low birth weight babies, which was similar to Deepa H. Velankar studies. Other studies (Hirve SS, Ganatra BR is $29.5 \%$, Ganesh Kumar et al 18\%) reported lesser value when compared to our study.

Preconceptional weight less than $40 \mathrm{~kg}$ in our study is 32 $(12.8 \%)$ of mothers with low birth weight babies, which was less than other studies (Ganesh Kumar et al 33\%, Mukesh K Sharma et al 50\%, KS Nagi et al 47\%). ${ }^{17,15,12}$

The maternal weight gain of less than $7 \mathrm{~kg}$ during pregnancy in our study was found to be 59 (23.6\%) in mothers with low birth weight babies, which is similar to J. S Deshmuk et al. ${ }^{21}$ 


\begin{tabular}{|c|c|c|c|}
\hline $\begin{array}{l}\text { Sl. } \\
\text { No. }\end{array}$ & Author of Study & $\begin{array}{c}\text { Incidence of } \\
\text { Anaemia }\end{array}$ & $\begin{array}{c}\text { Our } \\
\text { Study }\end{array}$ \\
\hline 1 & $\begin{array}{l}\text { Lt. Col. G Singh, R Chouhan, } \\
\text { Maj. K Sidhu } 18\end{array}$ & $18 \%$ & \multirow{3}{*}{$60.8 \%$} \\
\hline 2 & S Ganesh Kumar et al ${ }^{17}$ & $36 \%$ & \\
\hline 3 & J S Deshmuk et al ${ }^{21}$ & $54 \%$ & \\
\hline
\end{tabular}

A haemoglobin of $10 \mathrm{gm} \%$ as anaemia is a maternal risk factor for low birth weight.

In the present study, $60.8 \%$ of the mothers of low birth weight babies are anaemic. Other studies reported lesser incidence of anaemia in mothers of low birth weight babies (Lt. Col. G Singh et al 18\%, S Ganesh Kumar et al 36\%, J S Deshmuk et al 54\%), as our Government Institute serves more poor people suffering from malnutrition and anaemia.

\begin{tabular}{|c|c|c|c|}
\hline Sl. No. & Author of Study & $\begin{array}{c}\text { \% of Mothers } \\
\text { with P.I.H }\end{array}$ & Our Study \\
\hline 1 & $\begin{array}{c}\text { K Dhal and R } \\
\text { Bagga }^{22}\end{array}$ & $8 \%$ & \multirow{3}{*}{$8 \%$} \\
\hline 2 & $\begin{array}{c}\text { S Ganesh Kumar et } \\
\text { al }^{17}\end{array}$ & $11 \%$ & \\
\hline 3 & $\begin{array}{l}\text { Hendrics C H, } \\
\text { Brenner W E } \\
(1971)^{23}\end{array}$ & $13.4 \%$ & \\
\hline
\end{tabular}

In the present study, $8 \%$ of mothers of low birth weight babies had pregnancy-induced hypertension. Some studies show comparatively more incidence of pregnancy-induced hypertension.

Regarding urinary tract infection with birth weight, there appears to be significant effect of UTI on birth weight of new born babies as evidenced from other studies. ${ }^{24,25}$ In our study, it is around $4 \%$ of mothers with low birth weight babies.

\section{CONCLUSION}

Low birth weight is still the major risk factor for infant mortality and morbidity in developing countries like India. The present study was done to know the incidence of low birth weight babies and the various maternal risk factors contributing to low birth weight.

The overall prevalence of low birth weight in our study was $18 \%$. The maternal factors observed to be significantly associated with low birth weight in our study include maternal age $<20$ years, maternal height $<145 \mathrm{cms}$, preconceptional weight $<40 \mathrm{~kg}$, weight gain $<7 \mathrm{~kg}$ during pregnancy, maternal anaemia and pregnancy-induced hypertension.

The results of this study suggest that to decrease the incidence of low birth weight babies is by various health programmes, which should focus on early identification of various maternal risk factors and appropriate management during the antenatal period by using the existing health services effectively are important for reducing burden of low birth weight babies in India.

\section{REFERENCES}

[1] Swamy VR. Disorders of weight and gestation. In: Singh M. edr. Care of the new born. $8^{\text {th }}$ edn. New Delhi: CBS Publishers and Distributors 2015; p. 299.
[2] Ryan CA, Ryan F, Keane E, et al. Trend analysis and socio-economic differentials in infant mortality in the Southern Health Board, Ireland (1988-1997). Ir Med J 2000;93(7):204-6.

[3] Gazi R, Karim F, Ali A. Low birth weight was the major predictor of infant deaths: evidence from a prospective study in rural Bangladesh. Brac Research Annual report. 2001.

[4] International Institution of Population services. Macro International. National Family Health Survey (NHFS3), 2005-06: India 2007; volume I: Mumbai: IIPS.

[5] Park JE, Park K. Textbook of preventive and social medicine. 24th edn. Jabalpur: Banarsidas Bhanot Publishers 2017.

[6] Nahar S, Mascie-Taylor CG, Begum HA. Maternal anthropometry as a predictor of birth weight. Public Health Nutr 2007:10(9):965-70.

[7] Lang S. Breastfeeding special care babies. Mod Midwife 1996;6(11):34-5.

[8] Paul VK, Radhika S, Deori AK, et al. Neurodevelopmental outcome of at risk nursing graduates. Indian Journal of Med Res 1998;107:113-7.

[9] Barker DJ. Early growth and cardiovascular disease. Arch Dis Child 1999;80(4):305-7.

[10] Romagnoli C, Luciano R, Rizzo C, et al. The growth of low-birth- weight neonate: assessment at 3 years. Minerva Pediatr 1993;45(3):75-81.

[11] Jayant DD, Phalke DB, Bangal VB, et al. Maternal risk factors for low birth weight neonates: a hospital based case control study in rural area of western Maharashtra, India. National Journal of Community Medicine 2011;2(3):394-398.

[12] Nagi KS, Kandpal SD, Kukreti M. The prominent factors associated with low birth weight. Indian Journal of Applied Research 2006;(8):31-4.

[13] Trivedi CR, Mavalankar DV. Epidemiology of low birth weight in Ahmedabad. Ind J Paed 1986;53(6):795800.

[14] Kamaladoss T, Abel R, Sampathkumar V. Epidemiology correlates of low birth weight in rural Tamil Nadu. Indian Journal of Paediatrics 1992;59(3): 299-304.

[15] Sharma M, Kumar D, Huria A, et al. Maternal risk factors of low birth weight in Chandigarh, India. The Internet Journal of Health 2008;9(1):1-4.

[16] Kapoor SK, Kumar G, Pandav CS, et al. Incidence of LBW in rural Ballabgarh, Haryana. Journal of Indian Paediatrics 2001;38(3):271-5.

[17] Kumar GS, Kumar HHN, Jayaram S, et al. Determinants of low birth weight: a case control study in a district hospital in Karnataka. Indian Journal of Pediatrics 2010;77(1):87-9.

[18] Singh G, Chouhan R, Sidhu K. Maternal factors for low birth weight babies. Medical Journal Armed Forces India 2009;65(1):10-12.

[19] Velankar DH. Maternal factors contributing to low birth weight babies in an urban slum community of greater Mumbai. Bombay Hospital Journal 2009;51(1):26-35.

[20] Hirve SS, Ganatra BR. Determinants of low birth weight: a community based prospective cohort study. Indian Paediatrics 1994;31(10):1221-5. 


\section{Jemds.com}

[21] Dougherty CRS, Jones AD. The determinants of birth weight. Am J Obstet Gynecol 1982;144(2):190-200.

[22] Dhall K, Bagga R. Maternal determinants of birth weight of north Indian babies. Indian J Pediatrics 1995;62(3):333-44.

[23] Hendrics CH, Brenner WE. Toxaemia of pregnancy: relation between fetal weight, fetal survival and the maternal state. Am J Obstet and Gynecology 1971;109(2):225-33.
Original Research Article

[24] Dimetry SR, El-Tokhy HM, Abdo NM, et al. Urinary tract infection and adverse outcome of pregnancy. J Egypt Public Helath Assoc 2007;82(3-4):203-18.

[25] Martin A, Azimul SK, Matiur AKM, et al. Maternal socioeconomic and nutritional determinants of low birth weight in urban area of Bangladesh. J Dhaka Med Coll 2008;17(2):83-7. 